\title{
Intracellular pH regulation by acid-base transporters in mammalian neurons
}

\section{Vernon A. Ruffin *, Ahlam I. Salameh, Walter F. Boron and Mark D. Parker ${ }^{\dagger}$}

Department of Physiology and Biophysics, Case Western Reserve University, OH, USA

Edited by:

Mario L. Diaz, Universidad de La

Laguna, Spain

Reviewed by:

Alberto Passi, Università

dell'Insubria, Italy

Mitchell Chesler, New York

University School of Medicine, USA

*Correspondence:

Vernon A. Ruffin, Department of

Physiology and Biophysics, Case

Western Reserve University, 10900

Euclid Ave., Cleveland, $\mathrm{OH} 44106$,

USA

e-mail:vernon.ruffin@case.edu

${ }^{\dagger}$ Present address:

Mark D. Parker, Department of

Physiology and Biophysics, State

University of New York at Buffalo,

NY, USA

\section{pH AND NEURONAL EXCITABILITY}

The excitability of neurons is especially sensitive to changes in intracellular $\mathrm{pH}\left(\mathrm{pH}_{\mathrm{i}}\right)$ and extracellular $\mathrm{pH}\left(\mathrm{pH}_{\mathrm{o}}\right)$ due to the $\mathrm{pH}$-sensitivity of intracellular and extracellular moieties on membrane proteins such as channels (Tombaugh and Somjen, 1996; Duprat et al., 1997; Waldmann et al., 1997; Ruffin et al., 2008), transporters (Irwin et al., 1994; Park et al., 2010; Adijanto and Philp, 2012), receptors (Giffard et al., 1990; Tang et al., 1990; Traynelis and Cull-Candy, 1990; McDonald et al., 1998), and ATPase pumps (Pick and Karlish, 1982; Wolosker et al., 1997). Together these proteins (1) govern the resting membrane potential of neurons, (2) affect neuronal responsiveness to agonists and antagonists, (3) set the threshold for firing an action potential, (4) influence the duration/amplitude of the action potential, (5) determine the length of the refractory period, and (6) synchronize neuronal network activity. These properties endow neurons with the ability to communicate with other neurons and glial cells within the nervous system (for functions such as learning, behavior, conscious thought, and unconscious homeostatic regulation), and with cells outside the nervous system (for functions such as motor control and endocrine regulation). Table 1 list examples of $\mathrm{pH}$ sensitive proteins and activities involved in setting neuronal excitability. The relationship between $\mathrm{pH}$ and neuronal excitability has been extensively reviewed by others (Balestrino and Somjen, 1988; Church, 1992; Tombaugh and Somjen, 1996; Dean et al., 2001; Makani and Chesler, 2007; Pavlov et al., 2013). Note that the link between $\mathrm{pH}$ and neuronal excitability is not a simple one: some neurons (e.g., chemosensitive neurons) exhibit enhanced excitability in response to an acid-load, whereas others (e.g., hippocampal neurons) may exhibit reduced excitability. The direction of the response presumably depends on the
$\mathrm{pH}$-responsiveness of the individual channels, transporters, and receptors that are responsible for dictating overall excitability in each neuron.

Glial cells are not excitable cells and experience only small changes in membrane potential compared to neurons. Although glial cells are not the focus of this review, it is important to address their critical role in optimal brain function. Traditionally, glial cells have been called neural supportive cells because they produce growth factors and recycle neurotransmitters (astrocytes), assist in rapid electrical transmission (oligodendrocytes), and scavenge compromised cells in addition to cellular debris (microglia). Glia, together with choroid plexus epithelia (Schmitt et al., 2000; Damkier et al., 2010a; Christensen et al., 2013), control the composition-including the $\mathrm{pH}$-of the extracellular cerebrospinal fluid (CSF) that bathes neurons (Chesler and Kraig, 1989; Deitmer and Rose, 1996; Bevensee et al., 1997; Brookes, 1997; Chesler, 2003; Ro and Carson, 2004; Ekdahl et al., 2009).

Models of seizure indicate that the acidification that follows intense firing (Chesler and Kaila, 1992; Jacobs et al., 2008), a phenomenon that likely forms part of a mechanism that prevents excessive firing by dampening neuronal excitability (Hormuzdi et al., 2004), is a major challenge to neuronal pH. Intriguingly, the main clinical presentations of several neurodegenerative disease states include signs of decreased brain $\mathrm{pH}$. Examples include Alzheimer's disease (Demetrius and Simon, 2012), Parkinson's disease (Mattson et al., 1999), and multiple sclerosis (Vergo et al., 2011). Even disease states originating outside of the brain (e.g., metabolic acidosis) can affect the $\mathrm{pH}$ of the brain. Given the link between $\mathrm{pH}$ and neuronal function, it is probable that such alterations in $\mathrm{pH}$ compromise brain function, contributing to the neurological symptoms of these diseases. 
Table 1 | Examples of pH-sensitive membrane proteins expressed in neurons.

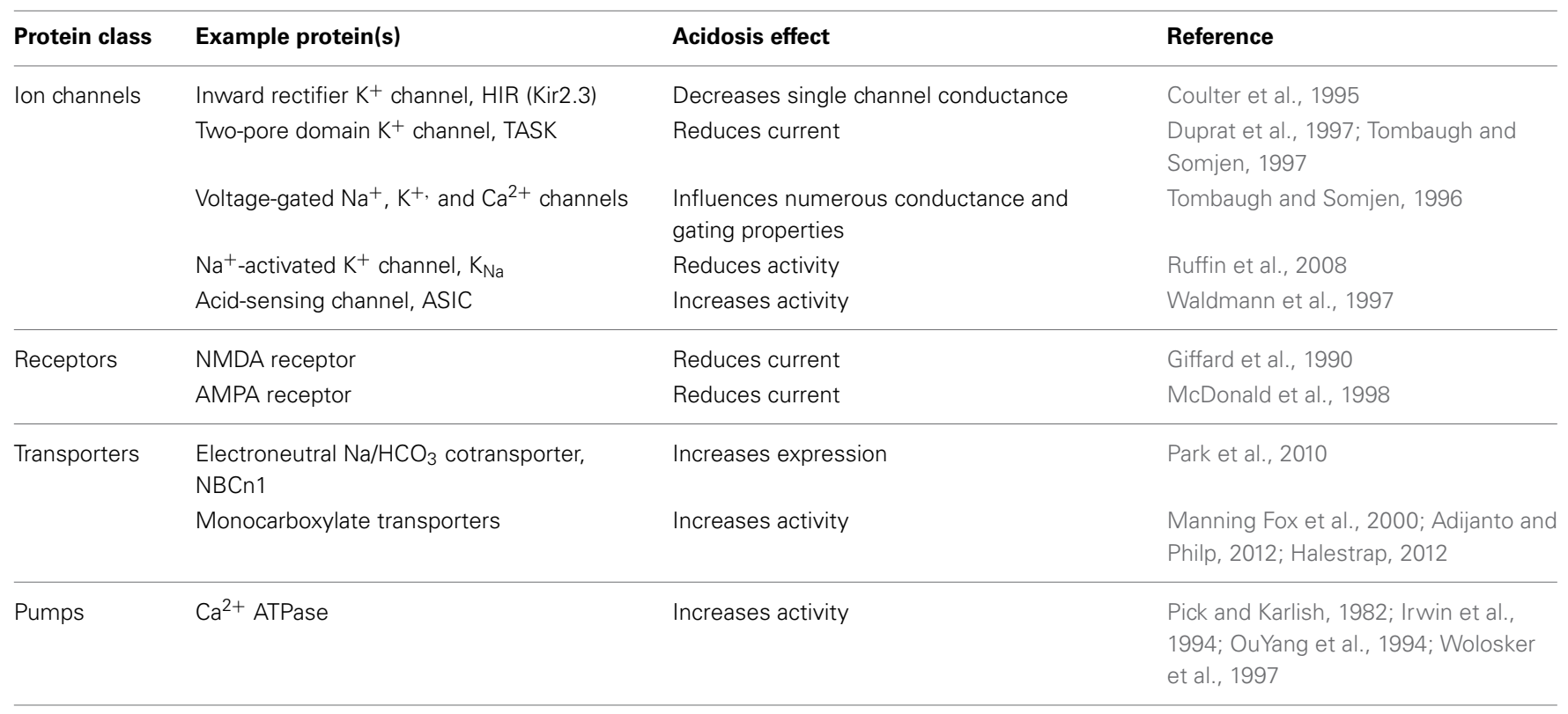

The regulation of cytosolic $\mathrm{pH}$ in most cells, including neurons, is an active process, since $\mathrm{H}^{+}$ions are not passively distributed across the cell membrane (Roos and Boron, 1981). In this brief review, we will provide an overview of the nature, function, and importance of the major acid-loading and acid-extruding proteins that contribute to neuronal $\mathrm{pH}$ homeostasis. We will also consider the pathologies that are associated with defective neuronal acid-base homeostasis and how the homeostatic systems respond in the face of pathological acid-base disturbances.

\section{NEURONAL pH HOMEOSTASIS}

Pioneering work in invertebrate models first identified the importance of neuronal $\mathrm{pH}$ regulation (Boron and De Weer, 1976a,b; Thomas, 1976). In vertebrates, extensive research has been performed on $\mathrm{pH}$ regulation in hippocampal neurons. The typical resting or "steady-state" $\mathrm{pH}_{\mathrm{i}}$ of a hippocampal neuron in $\mathrm{CO}_{2} / \mathrm{HCO}_{3}^{-}$-containing media is $\sim 7.03-7.46$. depending on the preparation, whereas the $\mathrm{pH}_{\mathrm{o}}$ is $\sim 7.35$ (Raley-Susman et al., 1991, 1993; Schwiening and Boron, 1994; Baxter and Church, 1996; Bevensee et al., 1996; Church et al., 1998; Smith et al., 1998; Vincent et al., 1999). Steady-state $\mathrm{pH}_{\mathrm{i}}$ is dependent on the balance between the rate of acid loading $\left(J_{\mathrm{L}}\right.$, i.e., rate of acid influx/generation or alkali efflux/consumption) and the rate of acid extrusion $\left(J_{\mathrm{E}}\right.$, i.e., rate of acid efflux/consumption or alkali influx/generation). Steady state $\mathrm{pH}_{\mathrm{i}}$ is achieved when $J_{\mathrm{E}}=J_{\mathrm{L}}$ (intersection of red and blue lines in Figure 1A). It is important to note that, at steady-state, the opposing acid-loading and acidextruding processes are not stopped but are proceeding at equal rates, thus their combined action results in no $\mathrm{pH}$ change.

Acid loading in neurons-a process that tends to lower $\mathrm{pH}_{\mathrm{i}}-$ predominantly results from the accumulation of metabolically generated $\mathrm{H}^{+}$(such as that produced by aerobic or anaerobic metabolism during neuronal firing: Chesler, 2003) and the extrusion of $\mathrm{HCO}_{3}{ }^{-}$from cells via a $\mathrm{Cl}-\mathrm{HCO}_{3}$ (anion) exchanger of the SLC4 solute carrier family (see section titled The ChlorideBicarbonate Exchanger AE3 and Figure 1B). Acid-loading processes tend to restore steady-state $\mathrm{pH}_{\mathrm{i}}$ after an alkali load.

Acid extrusion-a process that tends to raise $\mathrm{pH}_{\mathrm{i}}$ - in neurons is typically achieved by the action of the SLC4 and SLC9 families of $\mathrm{Na}^{+}$-coupled transport proteins. Both transporter families that take advantage of the inwardly directed $\mathrm{Na}^{+}$gradient established by the $\mathrm{Na}^{+}, \mathrm{K}^{+}$ATPase to either extrude $\mathrm{H}^{+}$from the cell (in the case of $\mathrm{Na}-\mathrm{H}$ exchangers (NHEs), see section titled SodiumHydrogen Exchangers NHE1, NHE3, and NHE5 and Figure 1B) or to accumulate a weak base, such as $\mathrm{HCO}_{3}{ }^{-}$(in the case of $\mathrm{Na} / \mathrm{HCO}_{3}$ cotransporters, see section titled Sodium-coupled Bicarbonate Transporters and Figure 1B). Acid-extruding processes tend to restore steady-state $\mathrm{pH}_{\mathrm{i}}$ after an acid load, such as that which might result from intense neuronal activity (Chesler and Kraig, 1989; Kaila et al., 1991).

Of course, transmembrane acid-loading processes tend to alkalinize the cell surface (raise $\mathrm{pH}_{\mathrm{s}}$ ) and transmembrane acidextruding processes tend to acidify the cell surface (lower $\mathrm{pH}_{\mathrm{s}}$ ), thereby also potentially impacting the function of membrane proteins in the brain with extracellular $\mathrm{pH}$-sensitive moieties. In practice, extracellular membrane-associated carbonic anhydrases catalyze the interconversion of $\mathrm{H}^{+}+\mathrm{HCO}_{3}{ }^{-} \leftrightarrow \mathrm{CO}_{2}+\mathrm{H}_{2} \mathrm{O}$ at the cell surface, which would tend to promote dissipation of $\mathrm{pH}$ gradients. A consideration of the $\mathrm{CO}_{2} / \mathrm{HCO}_{3}^{-}$buffering system and whole-body $\mathrm{pH}$ homeostasis is provided elsewhere (Giebisch and Windhager, 2009; Boron, 2012; Bevensee and Boron, 2013).

\section{NEURONAL ACID-BASE TRANSPORTERS ACID LOADERS}

The chloride-bicarbonate exchanger AE3

Molecular identity. The main acid loader that is predicted to contribute to $\mathrm{J}_{\mathrm{L}}$ in neurons is the $\mathrm{Cl}-\mathrm{HCO}_{3}$ exchanger AE3 (Anion Exchanger 3, encoded by the SLC4A3 gene). AE3 was the third 

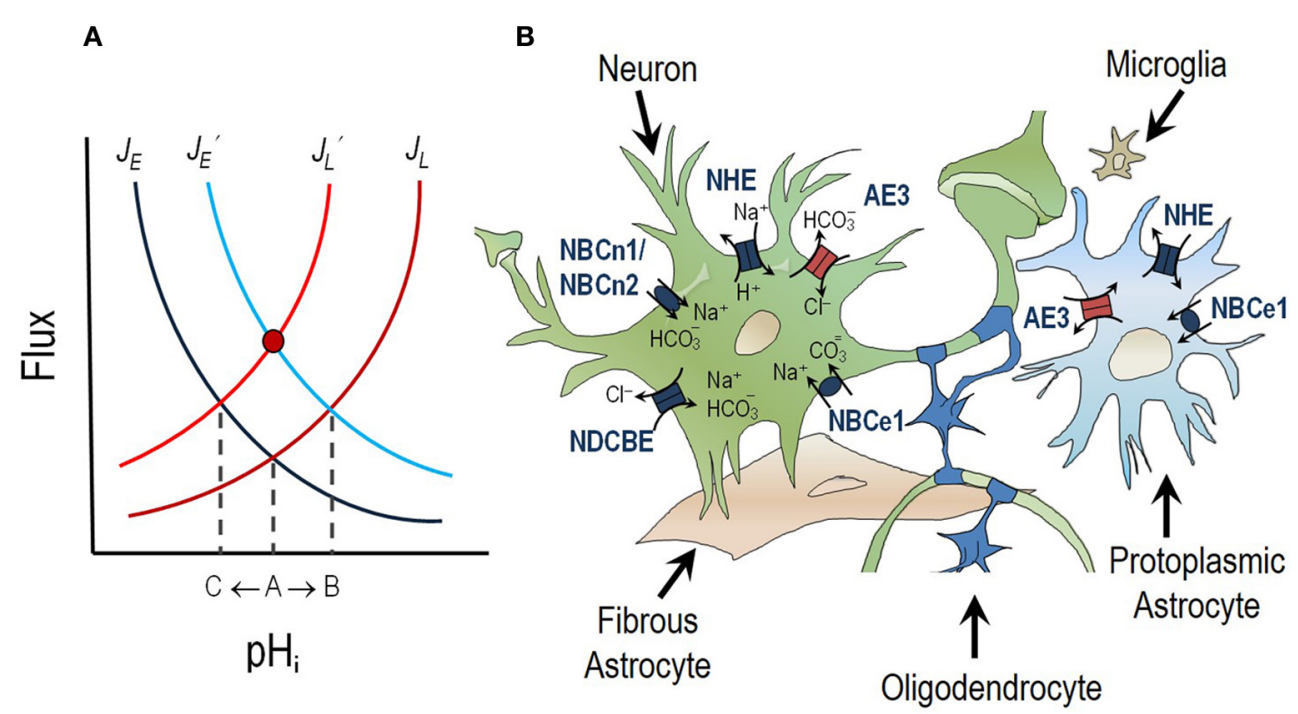

FIGURE 1 | pH regulation in the central nervous system. (A) Steady-state $\mathrm{pH}_{\mathrm{i}}$ is dependent on the balance between the rate of acid extrusion $\left(J_{E}\right)$ and the rate of acid loading $\left(J_{L}\right)$. Steady-state $\mathrm{pH}_{\mathrm{i}}$ is achieved when $J_{E}=J_{L}$ (intersection of dark-blue and dark-red lines: point A). If $J_{E}$ increases $\left(J_{E}^{\prime}\right)$ the steady-state $\mathrm{pH}_{\mathrm{i}}$ will shift to a more alkaline value (intersection of light-blue and dark-red lines: point $B$ ). If $J_{L}$ increases $\left(J_{L}^{\prime}\right)$ the steady-state $\mathrm{pH}$ will shift to a more acidic value (intersection of dark-blue and light-red lines: point $C$ ). If the rise in $J_{E}$ is matched by an equal increase in $J_{L}\left(J_{E}^{\prime}=J_{L}^{\prime}\right)$ there will be no net change in $\mathrm{pH}_{\mathrm{i}}$ (red circle). This is known as a compensatory response. (B) Neurons, astrocytes and oligodendrocytes express two classes of acid-base transporting proteins; acid loaders (red) and acid extruders (dark blue). member of the 10 members of the SLC4 solute carrier family to be cloned and characterized and, like its close relatives AE1 and AE2 (Alper, 2009), mediates the stilbene-sensitive, electroneutral exchange of one $\mathrm{Cl}^{-}$for one $\mathrm{HCO}_{3}^{-}$(Sterling and Casey, 1999). As we will see later, not all SLC4 members are acid loaders: indeed the majority are acid extruders (see $\mathrm{Na}^{+}$-coupled $\mathrm{HCO}_{3}{ }^{-}$transporters, SLC4A4-8 in Section titled Sodium-coupled Bicarbonate Transporters). In mammals SLC4A3 encodes two alternative gene products: bAE3 (abundant in the brain, often referred to as AE3fl, full-length) and cAE3 (abundant in cardiac tissue). bAE3 is expressed from a different promoter than cAE3 and includes a longer and different $\mathrm{Nt}$ appendage. Artificial truncation of the bAE3-specific sequence appears to confer a lesser functional expression on the transporter, consistent with the hypothesis that this sequence is autostimulatory. The appendage has also been reported to include two $\mathrm{SH} 3$ domains and a $\mathrm{PKC}$ site indicating a possible role for modulation by extrinsic signals (Sterling and Casey, 1999; Alvarez et al., 2001).

Distribution. bAE3 transcripts and protein are expressed throughout the central nervous system. In mice, bAE3 transcripts are especially abundant in pyramidal neurons of the hippocampal (HC) formation (Kopito et al., 1989; Hentschke et al., 2006) although western blotting of brain regions shows AE3 protein to be similarly abundant in the cerebral cortex (CX), cerebellum (CB), and brainstem-diencephalon (BD): (Xue et al., 2003). Western blotting of fractionated cells suggests that AE3 protein expression in the brain is mainly in neurons rather than in astrocytes (Hentschke et al., 2006). However, in the retina of rats, bAE3 is located in the basal end feet of Müller cells (glia) and it is cAE3 that is expressed in horizontal cells (neurons): (Kobayashi et al., 1994; Alvarez et al., 2007).
Influence on neuronal $\mathbf{p H}_{\boldsymbol{i}} \cdot \mathrm{Cl}-\mathrm{HCO}_{3}$ exchange is a feature of adult neurons and $\mathrm{AE} 3$ is the sole $\mathrm{Cl}-\mathrm{HCO}_{3}$ exchanger in neurons as evidenced by the absence of $\mathrm{Cl}-\mathrm{HCO}_{3}$ exchange activity in AE3-null mice (Hentschke et al., 2006). Interestingly, despite evidence for the presence of AE3 transcripts in embryonic mouse and rat brain, (Hentschke et al., 2006) neurons from fetal mice exhibit no substantial $\mathrm{Cl}-\mathrm{HCO}_{3}$ exchange activity as if $\mathrm{AE} 3$ protein is absent or otherwise indisposed (Raley-Susman et al., 1993; Vilas et al., 2009). However, as mentioned below, AE3-like activity is evident as a damping mechanism when acid-extruders are in robust operation. Due to the prevailing ion gradients and probably also due to the relative substrate affinities of the intracellular and extracellular ion translocation sites, AE3 typically extrudes $\mathrm{HCO}_{3}{ }^{-}$in exchange for extracellular $\mathrm{Cl}^{-}$, thereby tending to lower $\mathrm{pH}_{\mathrm{i}}\left(\right.$ raise $\left.\mathrm{pH}_{\mathrm{s}}\right)$ and raise $\left[\mathrm{Cl}^{-}\right]_{\mathrm{i}}$. Evidence for the role of AE3 as an acid loader is provided by the observations that (1) COS cells expressing AE3 exhibit a markedly lower $\mathrm{pH}_{\mathrm{i}}$ than control cells that do not express AE3 (Kopito et al., 1989) and (2) hippocampal neurons from embryonic mice exhibit an enhanced rate of acid-extrusion in the presence of DIDS or in the absence of extracellular $\mathrm{Cl}^{-}$: both maneuvers that would block AE3 action (Svichar et al., 2009). Furthermore, HC neurons from adult Ae3null mice exhibit a slightly higher $\mathrm{pH}_{\mathrm{i}}$ than wild-type neurons, although the authors of the study note that the $\mathrm{pH}$ difference did not achieve statistical significance in their study (Hentschke et al., 2006). A Cl- $\mathrm{HCO}_{3}$ exchanger, likely $\mathrm{AE} 3$, also contributes to $J_{\mathrm{L}}$ in non-chemosensitive and some chemosensitive neurons of the medulla oblongata (Ritucci et al., 1998; Meier et al., 2007).

Importance for neuronal function. Mice lacking acid-extruders of the SLC4 family tend to exhibit evidence of reduced neuronal excitability (see section titled Sodium-coupled Bicarbonate 
Transporters), thus it seems fitting that a missense mutation in AE3, an acid-loader, is associated with idiopathic generalized epilepsy (Sander et al., 2002). Subsequent work has shown that the mutant AE3 is functionally defective in a heterologous system (Vilas et al., 2009). Moreover, a strain of Ae3-null mouse exhibits lower seizure threshold in response to proconvulsants and a greater seizure-mortality consistent with enhanced neuronal excitability (Hentschke et al., 2006). Ae3-null mice exhibit a reduced respiratory rate consistent with a contribution to the resting $\mathrm{pH}$ in chemosensitive neurons that, unlike other neurons, are stimulated by lowered $\mathrm{pH}_{\mathrm{i}}$ (Meier et al., 2007). Finally, in the mouse retina, the importance of AE3 for maintaining appropriate electrical excitability is indicated by the association of AE3-deficiency with blindness (Alvarez et al., 2007). However, it is not clear if any of these indicators of altered neuronal excitability are entirely due to defective $\mathrm{pH}$ regulation, or if they are related to altered $\mathrm{Cl}^{-}$accumulation, another factor known to influence neuronal excitability (Irie et al., 1998; Kahle et al., 2005).

\section{ACID EXTRUDERS}

In neurons and astrocytes, the main acid extruders contributing to $J_{\mathrm{E}}$ are the NHEs in the SLC9 family of solute carriers (recently reviewed by Donowitz et al., 2013) and the $\mathrm{Na}^{+}$-coupled $\mathrm{HCO}_{3}{ }^{-}$ transporters (NCBTs) in the SLC4 family (recently reviewed by Parker and Boron, 2013).

\section{Sodium-hydrogen exchangers NHE1, NHE3, and NHE5}

Molecular identity. The main $\mathrm{HCO}_{3}$-independent acid loaders that are predicted to contribute to $J_{\mathrm{E}}$ in neurons and astrocytes are the NHEs (Orlowski and Grinstein, 2004; Donowitz et al., 2013). NHE1 (neurons and astrocytes), NHE3 (chemosensitive neurons), and NHE5 (neurons) are encoded by the SLC9A1, SLC9A3, and SLC9A5 genes, respectively. Three of five members of the SLC9 family mediate the electroneutral exchange of one $\mathrm{Na}^{+}$for one $\mathrm{H}^{+}$across the plasma membrane. The other four other members, NHE6-NHE9, are intracellular K-H exchangers. The general topology and relatedness of family members are show in Figures 2A,B. SLC9 family members have a short $\mathrm{Nt}$ and an extensive $\mathrm{Ct}$ that plays a regulatory role (Orlowski and Grinstein, 2004; Donowitz et al., 2013). NHE1 is far more sensitive to amiloride derivatives than either NHE3 or NHE5 (Counillon et al., 1993; Orlowski, 1993).

Distribution. NHE1 exhibits the broadest distribution of all the NHE isoforms throughout the body and has been identified in multiple brain regions (Ma and Haddad, 1997; Kanaan et al., 2007), both in neurons (e.g., cultured mouse HC and neocortical neurons: Sin et al., 2009; Diering et al., 2011) and astrocytes (e.g., cultured rat HC astrocytes: Pizzonia et al., 1996). NHE3 exhibits robust expression in cerebellar Purkinje cells ( $\mathrm{Ma}$ and Haddad, 1997) and also in chemosensitive, ventrolateral neurons in the brainstem/medulla oblongata (Wiemann et al., 1999, 2005; Kiwull-Schöne et al., 2001, 2007). NHE5 expression is predominantly detected in the brain (Klanke et al., 1995; Attaphitaya et al., 1999) with robust expression in multiple brain regions (Attaphitaya et al., 1999; Baird et al., 1999). At the subcellular level, NHE5 protein has been detected in the synapses of HC pyramidal neurons of mice in both a subset of inhibitory and excitable synapses (Diering et al., 2011).

Influence on neuronal $\mathrm{pH}_{i}$. Due to the prevailing ion gradients, NHEs typically extrude $\mathrm{H}^{+}$in exchange for extracellular $\mathrm{Na}^{+}$ (taking advantage of the inwardly directed gradient for $\mathrm{Na}^{+}$), thereby tending to raise $\mathrm{pH}_{\mathrm{i}}$ (e.g., while restoring steady-state $\mathrm{pH}_{\mathrm{i}}$ after an acid load) and lower $\mathrm{pH}_{\mathrm{s}}$. Evidence for the role of NHE1 as an acid extruder is provided by the observation that CA1 neurons from Nhe1-null mice exhibit a significantly lower steady-state $\mathrm{pH}_{\mathrm{i}}$ than wild-type neurons (7.17 vs 7.25) and a slower recovery from $\mathrm{NH}_{4}$-induced acid-loads: with some individual neurons being completely unable to recover from the acid-load in the absence of $\mathrm{HCO}_{3}^{-}$(Yao et al., 1999). NHE1 is also a major contributor to $\mathrm{pH}_{\mathrm{i}}$ recovery in chemosensitive neurons of the retrotrapezoid nucleus (RTN) and nucleus tractus solitarius (NTS) (Kersh et al., 2009). In addition to the direct effects of NHE1 absence, loss of NHE1 also has indirect effects on the mechanism of neuronal $\mathrm{pH}_{\mathrm{i}}$ regulation due to the compensatory downregulation of $\mathrm{AE} 3$ in the $\mathrm{HC}$ and upregulation of NHE3 (in the CB) and NBCe1 (in the BD), all of which would tend to compensate for the loss of NHE1-mediated $J_{\mathrm{E}}$ (Xue et al., 2003).

The importance of NHE3 to $\mathrm{pH}$ regulation in chemosensitive neurons is indicated by the following studies: (1) inhibition of NHE3 lowers the steady-state $\mathrm{pH}_{\mathrm{i}}$ of medullary raphé chemosensitive neurons by 0.1 unit (Wiemann et al., 1999) and (2) pharmacological data suggests that NHE3 contributes, along with NHE1, to $J_{\mathrm{E}}$ in RTN neurons (Kersh et al., 2009).

One study of cultured HC neurons revealed that NHE5 contributes to acid-extrusion in the dendritic spine during enhanced neuronal activity (effected by NMDA receptor activation), a process that would tend to acidify the synaptic cleft $\left(\mathrm{pH}_{\mathrm{s}}\right)$ : (Diering et al., 2011).

Importance for neuronal function. A spontaneous slow wave epilepsy was mapped to a null-mutation in the Nhe1 gene locus in one strain of mouse, (Cox et al., 1997) a finding that was bolstered by the exhibition by targeted-null mice of ataxia, apparent absence-seizures, and a post-mortem appearance consistent with seizure-related death (Bell et al., 1999). Indeed, CA1 neurons from spontaneously Nhe1-null mice are demonstrated to have enhanced excitability compared to wild-type neurons ( $\mathrm{Gu}$ et al., 2001; Xia et al., 2003). However, the underlying cause is complex because other changes are detected in these neurons that would tend to enhance excitability, such as increased $\mathrm{Na}^{+}$channel density (Gu et al., 2001; Xia et al., 2003), and a reduction of delta-opioid receptor expression (Zhao et al., 2005).

Chemosensitive neurons are unusually stimulated by acidification, a phenomenon that serves to stimulate exhalation of $\mathrm{CO}_{2}$ (a potential acid) during acidosis. Three lines of evidence suggest that NHE3 plays a role in maintaining steady-state $\mathrm{pH}_{\mathrm{i}}$ in these cells, thereby setting resting ventilation rate: (1) in rats, NHE3 blockade results in a lowering of $\mathrm{pH}_{\mathrm{i}}$, causing a great increase in bioelectric activity (Wiemann et al., 1999; Kiwull-Schöne et al., 2001), (2) systemic application of an NHE3 blocker to rats causes an increased respiratory frequency (Ribas-Salgueiro et al., 2009), 


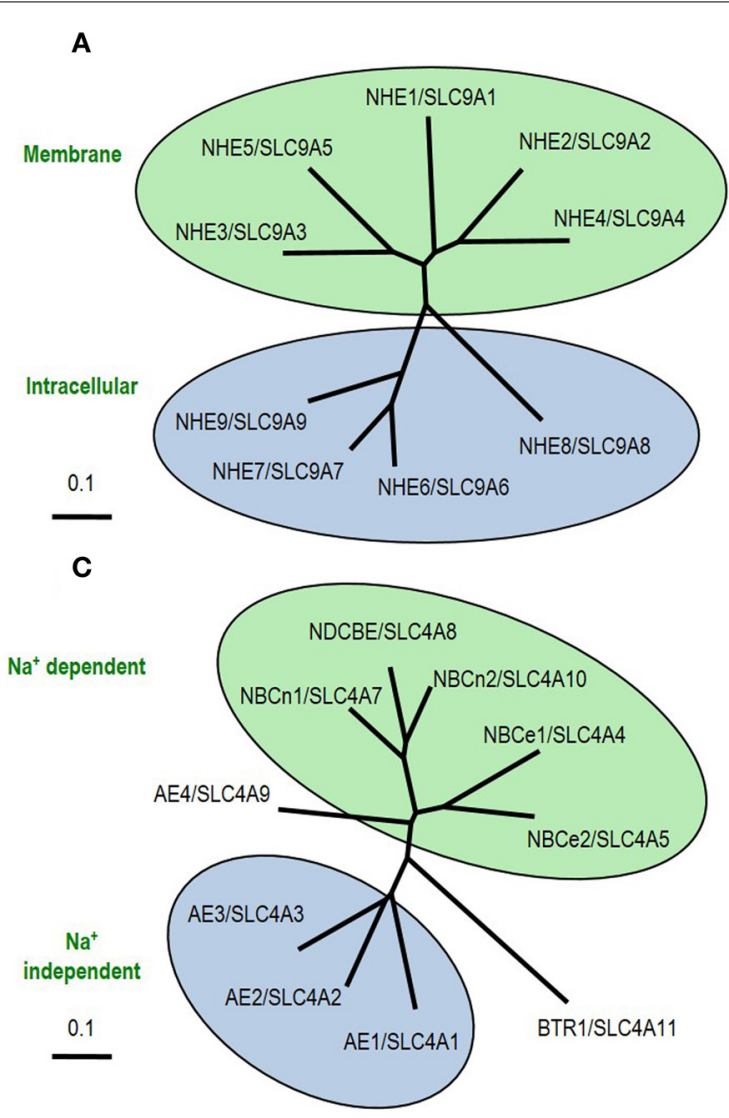

FIGURE 2 | Neuronal acid-base transporters of the SLC9 and SLC4 families. (A) The relatedness of SLC9 family proteins. (B) The general topology of SLC9 proteins. The human SLC9 gene family of solute carriers consists of 9 members which encode proteins containing a $\sim 450$ aa $\mathrm{N}$-terminus composed of 12 membrane spans that form the transmembrane domain (TMD) where the exchange of extracellular $\mathrm{Na}^{+}$and intracellular $\mathrm{H}^{+}$ occurs, and a C-terminus of varying length ( 125-440 aa) depending on
B

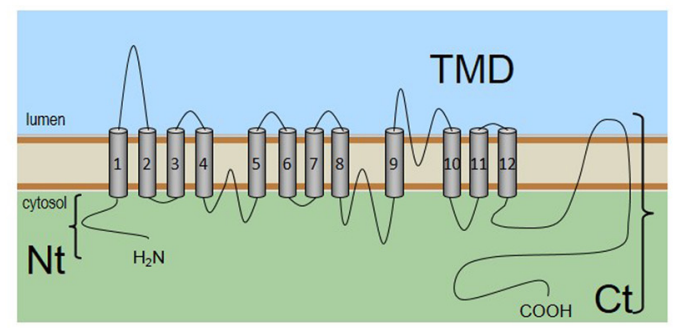

D

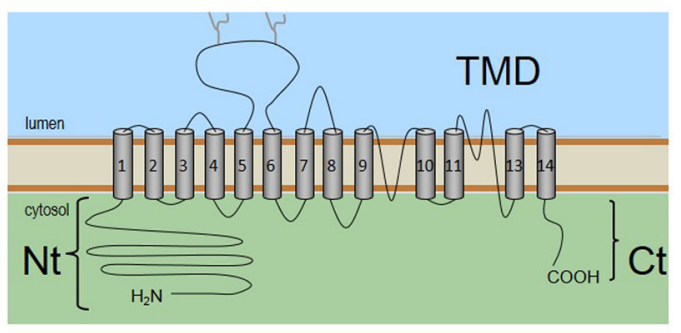

isoform, that is involved in the regulation of exchange activity. (C) The relatedness of SLC4 family proteins. (D) The general topology of SLC4 proteins. The extended $\mathrm{N}$-terminus and $\mathrm{C}$-terminus are linked via a TMD that includes 14 transmembrane spans, one of which (transmembrane span 12) is believed to be an extended non-helical region. Each NCBT gene encodes multiple products that differ from each other in their extreme $\mathrm{Nt}$ or $\mathrm{Ct}$ sequence (Boron et al., 2009). and (3) rabbits with lower NHE3 mRNA abundance tend to exhibit greater ventilation rates than these with a higher NHE3 mRNA abundance (Wiemann et al., 2005).

It has been suggested that NHE5 could play a critical role in the synaptic $\mathrm{pH}$ regulation during the firing of action potentials. In cultured hippocampal neurons, the activation of NMDA receptors recruits NHE5 protein to the membrane surface where it not only fosters focal-synaptic-cleft acidification, but also suppresses activity-induced dendritic spine growth by an autocrine feedback mechanism (Diering et al., 2011). Accordingly, knockdown of NHE5 or overexpression of a dominant-negative mutant of NHE5 in cultured hippocampal neurons causes dendritic spine overgrowth (Diering et al., 2011).

\section{Sodium-coupled bicarbonate transporters}

Molecular identity. The main $\mathrm{HCO}_{3}$-dependent acid loaders that are predicted to contribute to $J_{\mathrm{E}}$ in neurons and astrocytes are the $\mathrm{Na}^{+}$-coupled $\mathrm{HCO}_{3}$ transporters (NCBTs): NBCe1, NBCn1, NDCBE, and NBCn2. NCBTs-like the acid loader AE3- are members of the SLC4 solute carrier family (Figure 2C) and share the same general topology (Figure 2D). However, unlike AE3, and more like NHEs, the common molecular action of NCBTs takes advantage of the inwardly directed $\mathrm{Na}^{+}$gradient to promote the influx of $\mathrm{HCO}_{3}{ }^{-}$, thereby tending to raise $\mathrm{pH}_{\mathrm{i}}$. $\mathrm{NBCe} 1$ (encoded by $\mathrm{SLC4A4}$ ) is an electrogenic $\mathrm{Na} / \mathrm{HCO}_{3}$ cotransporter that mediates the coupled influx of $1 \mathrm{Na}^{+}$plus $2 \mathrm{HCO}_{3}{ }^{-}$equivalents (Romero et al., 1997). NBCn1 (encoded by SLC4A7) is an electroneutral NCBT that mediates the coupled influx of $1 \mathrm{Na}^{+}$ and $1 \mathrm{HCO}_{3}{ }^{-}$equivalent; NBCn1 is unique among the NCBTs inasmuch as it exhibits a pronounced $\mathrm{HCO}_{3}{ }^{-}$-independent $\mathrm{Na}^{+}$ flux (Choi et al., 2000). NDCBE (SLC4A8) is a Na${ }^{+}$-driven Cl$\mathrm{HCO}_{3}$ exchanger that mediates the electroneutral exchange of 1 $\mathrm{Na}^{+}$plus $2 \mathrm{HCO}_{3}{ }^{-}$equivalents for $1 \mathrm{Cl}^{-}$(Grichtchenko et al., 2001). NBCn2/NCBE (SLC4A10) has a controversial molecular action in as much it is appears capable of NDCBE-like activity in under certain assay conditions (Wang et al., 2000; Parker et al., 2008; Damkier et al., 2010b) yet the protein expressed in Xenopus oocytes mediates NBCn1-like electroneutral $\mathrm{Na}^{+}$and $\mathrm{HCO}_{3}{ }^{-}$ cotransport alongside futile $\mathrm{Cl}-\mathrm{Cl}$ exchange cycles that result in no net movement of $\mathrm{Cl}^{-}$(Parker et al., 2008). The majority of SLC4 
members are inhibited by disulfonic stilbene derivatives such as DIDS, although NBCn1 is relatively poorly inhibited by DIDS (Choi et al., 2000).

Distribution. NBCe1 transcripts and protein are expressed throughout the central nervous system in both neurons and astrocytes (Majumdar et al., 2008). The three electroneutral NCBTs (NBCn1, NDCBE, and NBCn2) are also expressed throughout the brain-in fact the brain is the major site of expression for NDCBE and NBCn2 (Grichtchenko et al., 2001; Parker et al., 2008)_and are especially abundant in HC neurons (Damkier et al., 2007; Boedtkjer et al., 2008; Chen et al., 2008a,b; Jacobs et al., 2008; Cooper et al., 2009). All chemosensitive neurons from the medullary raphe appear to express all NCBTs in culture (Coley et al., 2013). In situ, NBCn1 expression has been detected in GABAergic and non-GABAergic HC neurons (Cooper et al., 2005) as well as in the post-synaptic dendritic spines of embryonic rat neurons (Cooper et al., 2005; Park et al., 2010). In addition, an NBCn1-like activity is present in locus coeruleus neurons (Kersh et al., 2009). NDCBE expression has been detected in presynaptic nerve endings of glutamatergic neurons, with a lesser presence in GABAergic neurons (Sinning et al., 2011; Burette et al., 2012). $\mathrm{NBCn} 2$ expression has been detected in pre- and post-synaptic compartments of GABAergic HC neurons (Sinning and Hübner, 2013).

Influence on neuronal $\mathbf{p H}_{\boldsymbol{i}}$. It has long been recognized that the $\mathrm{pH}_{\mathrm{i}}$ and the excitability of $\mathrm{HC}$ neurons is enhanced in the presence vs. the absence of $\mathrm{CO}_{2} / \mathrm{HCO}_{3}$ (Yao et al., 1999) and also that neuronal $J_{\mathrm{E}}$ is enhanced in the presence of $\mathrm{CO}_{2} / \mathrm{HCO}_{3}$ (Bevensee et al., 1996). Being expressed in neurons, all four of the NCBTs mentioned the in the previous section likely contribute to $J_{\mathrm{E}}$. Neurons from mice lacking NBCel (Svichar et al., 2011) and brain slices from mice lacking NBCn2 (Jacobs et al., 2008) exhibit substantial deficits in $J_{\mathrm{E}}$. However, we are not aware of any studies that directly address the role of NBCn1 or NDCBE in setting steady-state $\mathrm{pH}_{\mathrm{i}}$, or contributing to $J_{\mathrm{E}}$.

Importance for neuronal function. Individuals with mutations in NBCel often exhibit intellectual impairments that could be a result of dysfunctional neuronal $\mathrm{pH}_{\mathrm{i}}$ regulation (Igarashi et al., 2001, 2002; Horita et al., 2005; Demirci et al., 2006). However, these individuals also exhibit a severe metabolic acidosis (NBCe1 is required in the kidney maintain plasma $\mathrm{HCO}_{3}{ }^{-}$) that could itself disturb brain $\mathrm{pH}$ (see section titled Metabolic Acidosis).

Mice lacking NDCBE (Sinning et al., 2011) and NBCn2 (Jacobs et al., 2008) exhibit greater resistance to seizure-induction consistent with the hypothesis that these transporters are normally required to contribute to $J_{\mathrm{E}}$ and maintain neuronal excitability. Furthermore, in humans, the SLC4A10 (NBCn2) gene-locus is linked with epilepsy and autism (Sebat et al., 2007; Gurnett et al., 2008; Krepischi et al., 2010). However, as mentioned above in relation to AE3-null mice, both transporters are capable of influencing $\mathrm{Cl}^{-}$accumulation which may itself impact excitability. Another factor that cannot be ignored is that $\mathrm{NBCn} 2$ is expressed in the choroid plexus where it is a key player in a pathway that controls $\left[\mathrm{HCO}_{3}^{-}\right]$in the CSF (Jacobs et al., 2008), thus the effect of NBCn2 loss on neuronal excitability could have an indirect component. One other NCBT that we have not considered above is NBCe2, the second electrogenic NCBT, which is encoded by SLC4A5 (Sassani et al., 2002; Virkki et al., 2002). $\mathrm{NBCe} 2$ is another key player in CSF secretion by the choroid plexus (Bouzinova et al., 2005; Millar and Brown, 2008), a factor that likely underlies the reduced neuronal excitability evident in brain slices from Nbce2-null mice (Kao et al., 2011); expression of $\mathrm{NBCe} 2$ has not been demonstrated in neurons.

\section{OTHER PLASMA MEMBRANE PROTEINS THAT INFLUENCE NEURONAL $\mathrm{pH}$}

Although this review focuses on the major $\mathrm{pH}$ regulating protein in the brain, other factors contribute either directly or indirectly to $\mathrm{pH}_{\mathrm{i}}, \mathrm{pH}_{\mathrm{s}}$, and $\mathrm{pH}_{\mathrm{o}}$ through the influx or efflux of acid-base equivalents. For instance, the $\mathrm{H}^{+}$-coupled monocarboxylate transporters (MCT1-4) play major role in transporting carboxylic acids, e.g., lactate and pyruvate, between neurons and astrocytes which are then used as a source of energy (Adijanto and Philp, 2012; Choi et al., 2012). The activation of NMDA receptors induces a $\mathrm{Ca}^{2+}$ dependent $\mathrm{pH}_{\mathrm{i}}$ acidification in rat $\mathrm{HC}$ neurons (Irwin et al., 1994) that is likely due to $\mathrm{Ca}-\mathrm{H}$ exchange mediated by the $\mathrm{Ca}^{2+}$-ATPase (Makani and Chesler, 2010). The extent of the drop in neuronal $\mathrm{pH}_{\mathrm{i}}$ due to $\mathrm{Ca}^{2+}$-ATPase action during electrical activity is limited by a depolarization-induced alkalization that is likely mediated by the proton-efflux channel $\mathrm{H}_{\mathrm{V}} 1$ (Meech and Thomas, 1987; Cheng et al., 2008; Meech, 2012). Finally, we must not discount the contribution of acid-base transporters in the astrocytes (Chesler, 2003) and choroid plexus epithelia (Damkier et al., 2010a, 2013), cells that control the composition of the brain extracellular fluid and thus indirectly influence the $\mathrm{pH}$ of neurons.

\section{PHYSIOPATHOLOGICAL ACID-BASE DISTURBANCES}

The four major acid base disturbances in the body are respiratory acidosis, respiratory alkalosis, metabolic acidosis, and metabolic alkalosis. In the following section we will discuss (1) the cause of each of these disturbances, (2) the clinical presentation of these disturbances, (3) the effect of these disturbances on $\mathrm{pH}_{\mathrm{i}}$, (4) the effect of these $\mathrm{pH}$ changes on the acid base transporter activity, and (5) the way the body compensates for these disturbances using the respiratory and renal systems.

\section{RESPIRATORY ACIDOSIS (HYPERCAPNIA)}

Respiratory acidosis results from inability to eliminate, from the body, the $\mathrm{CO}_{2}$ that is produced from cellular respiration. As a consequence the partial pressure of $\mathrm{CO}_{2}\left(\mathrm{pCO}_{2}\right)$ in the blood rises and the $\mathrm{pH}$ of the blood decreases as described by the HendersonHasselbalch equation (Hills, 1973; Hurn et al., 1991). Some of the causes of respiratory acidosis are CNS depression, neuromuscular disease, chronic obstructive pulmonary disease (COPD), sleep apnea, alveolar hypoventilation, ischemia, lung disease, and obesity. Clinical symptoms of hypercapnia include anxiety, pulmonary hypertension, tachypnea, extrasystoles, muscle twitches, and reduced neural activity. Prolonged hypercapnia results in disorientation, convulsions, unconsciousness, and eventually death (Ayers and Warrington, 2008). 
Specialized neuronal groups (respiratory chemoreceptors) within the brain protect against the compromised neuronal function associated with ECF (extracellular fluid) acidosis. Respiratory chemoreceptors were first identified on the surface of the medulla (Mitchell et al., 1963; Loeschcke et al., 1970; Schlaefke et al., 1970), and later throughout the brainstem and hypothalamus (Berquin et al., 2000). Respiratory chemoreceptors chemically sense increased $\mathrm{CO}_{2}$ or $\mathrm{H}^{+}$production. In response to the stimulus of lowered $\mathrm{pH}_{\mathrm{i}}$ that accompanies this increased $\mathrm{CO}_{2}$ or $\mathrm{H}^{+}$production, the excitability of these cells is enhanced, which increases respiratory drive, thereby appropriately adjusting the $\mathrm{pH}$ of the ECF (blood, CSF, and interstitial fluid): (Douglas et al., 2001; Putnam, 2001; Bouyer et al., 2004; Richerson, 2004; Hodges and Richerson, 2010).

Longer term exposure to elevated $\mathrm{pCO}_{2}$ increases the expression of acid extruders (NHE1 and NBCn1) and decreases the expression of the acid loader AE3 throughout the mouse brain, mostly prominently in the cortex, and especially in neonates (Kanaan et al., 2007). This may reflect a compensatory mechanism that would counter acidosis and tend to maintain neuronal excitability. Recent data points to a potential genetic link between NHE3, breathing control, and sudden infant death syndrome (Wiemann et al., 2005, 2008; Poetsch et al., 2010).

\section{RESPIRATORY ALKALOSIS (HYPOCAPNIA)}

Respiratory alkalosis results from the excess elimination of $\mathrm{CO}_{2}$ from the body. As a result, $\mathrm{pCO}_{2}$ decreases and the $\mathrm{pH}$ of the blood increases. Some of the causes of respiratory alkalosis are hypoxia, hyperventilation, CNS disorders (meningitis), and drugs. The decrease in $\mathrm{CO}_{2}$ is usually well tolerated, although there are typical clinical symptoms that include confusion, dizziness, muscle cramps, chest wall tightness, and tetany in the extremities (Ayers and Warrington, 2008).

The main stimulus for ventilation is increased $\mathrm{CO}_{2}$, and as a result the decreased $\mathrm{pCO}_{2}$ present in respiratory alkalosis can suppress breathing. As breathing decreases, the $\mathrm{pCO}_{2}$ rises and returns the blood $\mathrm{pH}$ to lower values. The decreased breathing also results in decreased $\mathrm{O}_{2}$ intake resulting in hypoxia secondary to hypocapnia. In addition, respiratory alkalosis also causes cerebral vasoconstriction with concomitant cerebral hypoxia. Clinical treatment for respiratory alkalosis include supplemental oxygen or drug removal if the alkalosis is drug induced (Ayers and Warrington, 2008).

\section{METABOLIC ACIDOSIS}

Metabolic acidosis results from an increase in metabolic acid production or an inability to remove acid/reabsorb base in the kidneys. As a result there is a decrease in blood $\mathrm{pH}$. Some of the causes of metabolic acidosis include diarrhea, severe renal failure, lactic acidosis, ketoacidosis, and drug intoxication. Clinical symptoms include a low blood $\mathrm{pH}(<7.35)$, chest pain, decreased cardiac output, hypotension, increased calcium release, and muscle weakness. Patients often display deep, labored breathing patterns (Kussmaul respiration) described as "air hunger." Metabolic acidosis can lead to coma and death (Ayers and Warrington, 2008).
Similar to respiratory acidosis, the overall result of this insult is decreased blood $\mathrm{pH}$ and consequently increased ventilation rate. Metabolic acidosis causes upregulation of NHE3 (KiwullSchöne et al., 2007) and increase expression of NBCn1 in several brain regions (Cooper et al., 2009; Park et al., 2010). This predicted increase in $J_{E}$ would facilitate extra protection against intracellular and extracellular acid overload.

As an acute compensation, the body regulates the bicarbonate buffering system to drive the production of $\mathrm{CO}_{2}$ which can be eliminated through increased ventilation. The chemoreceptors in the brainstem and hypothalamus are activated and stimulate respiratory structures to increase breathing rate and elimination of $\mathrm{CO}_{2}$. The increased acid is also intrinsically buffered by proteins, phosphates, and carbonate in the bone. As a chronic compensation, the renal system increases the secretion of $\mathrm{H}^{+}$(Giebisch and Windhager, 2009). Clinical treatment for metabolic acidosis includes normalizing blood volume and cardiac output. For more severe cases bicarbonate and acetate are administered and $\mathrm{pCO}_{2}$ is decreased (Ayers and Warrington, 2008).

\section{METABOLIC ALKALOSIS}

Metabolic alkalosis results from an increase bicarbonate in the blood. This increase may be due to either a primary increase in bicarbonate reabsorption or be secondary to decreased production or increased loss of $\mathrm{H}^{+}$. As a result there is an increase in blood $\mathrm{pH}$. Some of the causes of metabolic alkalosis include vomiting, diuretics, or increased urinary excretion of $\mathrm{Cl}^{-}$. Clinical symptoms include arteriolar constriction, reduced coronary blood flow, hypokalemia, tetany, and seizures (Ayers and Warrington, 2008).

The increased blood $\mathrm{pH}$ reduces the respiratory stimulus for breathing and hypoventilation occurs. As a result $\mathrm{CO}_{2}$ is retained and shuttled through the carbonic anhydrase buffering system and $\mathrm{H}^{+}$is produced which lowers blood $\mathrm{pH}$. A more chronic compensation occurs when the renal system decreases $\mathrm{H}^{+}$secretion (Giebisch and Windhager, 2009). Clinical treatment for metabolic alkalosis includes volume replacement, use of carbonic anhydrase inhibitors (acetazolamide), and correction of potassium depletion (Ayers and Warrington, 2008). We are unaware of any reports of compensatory alterations in acid base transporter activity or expression in the brain under metabolic alkalosis.

\section{SUMMARY}

Neuronal excitability is highly susceptible to fluctuations in intraand extracellular $\mathrm{pH}$. It is the delicate balance between the actions of the acid-base transporters that contributes to $J_{\mathrm{L}}$ and $J_{\mathrm{E}}$, maintaining a permissive neuronal $\mathrm{pH}$ in the face of physiological and pathophysiological acid-base disturbances. Loss of any of these transporters is associated with profound neuronal abnormalities and conversely, disturbance in $\mathrm{pH}$ are associated with many different physiopathological conditions such as Alzheimer's and Parkinson's diseases. The contribution of acid-base transporters to the severity of the signs of neurological disorders is a promising area of investigation.

\section{ACKNOWLEDGMENTS}

Mark D. Parker is supported by start-up funds from the Dean of the School of Medicine and Biomedical Sciences and from the 
Department of Physiology and Biophysics at SUNY Buffalo. This work was also funded by grants from the National Institutes of Health to Walter F. Boron (NS18400) and to Michael L. Jennings and Mark D. Parker (EY021646).

\section{REFERENCES}

Adijanto, J., and Philp, N. J. (2012). The SLC16A family of monocarboxylate transporters (MCTs)—physiology and function in cellular metabolism, $\mathrm{pH}$ homeostasis, and fluid transport. Curr. Top. Membr. 70, 275-311. doi: 10.1016/B978-0-12-394316-3.00009-0

Alper, S. L. (2009). Molecular physiology and genetics of $\mathrm{Na}^{+}$-independent SLC4 anion exchangers. J. Exp. Biol. 212, 1672-1683. doi: 10.1242/ jeb.029454

Alvarez, B. V., Fujinaga, J., and Casey, J. R. (2001). Molecular basis for angiotensin II-induced increase of chloride/bicarbonate exchange in the myocardium. Circ. Res. 89, 1246-1253. doi: 10.1161/hh2401.101907

Alvarez, B. V., Gilmour, G. S., Mema, S. C., Martin, B. T., Shull, G. E., Casey, J. R., et al. (2007). Blindness caused by deficiency in AE3 chloride/bicarbonate exchanger. PLoS ONE 2:e839. doi: 10.1371/journal.pone.0000839

Attaphitaya, S., Park, K., and Melvin, J. E. (1999). Molecular cloning and functional expression of a rat $\mathrm{Na}^{+} / \mathrm{H}^{+}$exchanger (NHE5) highly expressed in brain. J. Biol. Chem. 274, 4383-4388. doi: 10.1074/jbc.274.7.4383

Ayers, P., and Warrington, L. (2008). Diagnosis and treatment of simple acid-base disorders. Nutr. Clin. Pract. 23, 122-127. doi: 10.1177/0884533608314534

Baird, N. R., Orlowski, J., Szabó, E. Z., Zaun, H. C., Schultheis, P. J., Menon, A. G., et al. (1999). Molecular cloning, genomic organization, and functional expression of $\mathrm{Na}^{+} / \mathrm{H}^{+}$exchanger isoform 5 (NHE5) from human brain. J. Biol. Chem. 274, 4377-4382. doi: 10.1074/jbc.274.7.4377

Balestrino, M., and Somjen, G. G. (1988). Concentration of carbon dioxide, interstitial $\mathrm{pH}$ and synaptic transmission in hippocampal formation of the rat. J. Physiol. 396, 247-266.

Baxter, K. A., and Church, J. (1996). Characterization of acid extrusion mechanisms in cultured fetal rat hippocampal neurones. J. Physiol. 493(Pt 2), 457-470.

Bell, S. M., Schreiner, C. M., Schultheis, P. J., Miller, M. L., Evans, R. L., Vorhees, C. V., et al. (1999). Targeted disruption of the murine Nhel locus induces ataxia, growth retardation, and seizures. Am. J. Physiol. 276, C788-795.

Berquin, P., Bodineau, L., Gros, F., and Larnicol, N. (2000). Brainstem and hypothalamic areas involved in respiratory chemoreflexes: a Fos study in adult rats. Brain Res. 857, 30-40. doi: 10.1016/S0006-8993(99)02304-5

Bevensee, M. O., and Boron, W. F. (2013). "Control of intracellular pH," in Seldin and Giebisch's The Kidney: Physiology and Pathophysiology, eds R. J. Alpern, M. J. Caplan, and O. W. Moe (San Diego, CA: Academic Press), 1773-1835. doi: 10.1016/B978-0-12-381462-3.00052-5

Bevensee, M. O., Cummins, T. R., Haddad, G. G., Boron, W. F., and Boyarsky, G. (1996). pH regulation in single CAl neurons acutely isolated from the hippocampi of immature and mature rats. J. Physiol. 494(Pt 2), 315-328.

Bevensee, M. O., Weed, R. A., and Boron, W. F. (1997). Intracellular pH regulation in cultured astrocytes from rat hippocampus. I. Role of $\mathrm{HCO}_{3}{ }^{-}$. J. Gen. Physiol. 110, 453-465. doi: 10.1085/jgp.110.4.453

Boedtkjer, E., Praetorius, J., Füchtbauer, E.-M., and Aalkjaer, C. (2008). Antibodyindependent localization of the electroneutral $\mathrm{Na}^{+}-\mathrm{HCO}_{3}{ }^{-}$cotransporter NBCn1 (slc4a7) in mice. Am. J. Physiol. Cell Physiol. 294, C591-C603. doi: 10.1152/ajpcell.00281.2007

Boron, W. (2012). "Acid-base physiology," in Medical Physiology, eds W. Boron and E. Boulpaep (Philadelphia, PA: Saunders Elsevier), 652-671.

Boron, W. F., Chen, L., and Parker, M. D. (2009). Modular structure of sodium-coupled bicarbonate transporters. J. Exp. Biol. 212, 1697-1706. doi: 10.1242/jeb.028563

Boron, W. F., and De Weer, P. (1976a). Intracellular pH transients in squid giant axons caused by $\mathrm{CO}_{2}, \mathrm{NH}_{3}$, and metabolic inhibitors. J. Gen. Physiol. 67, 91-112. doi: 10.1085/jgp.67.1.91

Boron, W. F., and De Weer, P. (1976b). Active proton transport stimulated by $\mathrm{CO}_{2} / \mathrm{HCO}_{3}{ }^{-}$, blocked by cyanide. Nature 259, 240-241. doi: 10.1038/259240a0

Bouyer, P., Bradley, S. R., Zhao, J., Wang, W., Richerson, G. B., and Boron, W. F. (2004). Effect of extracellular acid-base disturbances on the intracellular $\mathrm{pH}$ of neurones cultured from rat medullary raphe or hippocampus. J. Physiol. 559, 85-101. doi: 10.1113/jphysiol.2004.067793
Bouzinova, E. V., Praetorius, J., Virkki, L. V., Nielsen, S., Boron, W. F., and Aalkjaer, C. (2005). $\mathrm{Na}^{+}$-dependent $\mathrm{HCO}_{3}^{-}$uptake into the rat choroid plexus epithelium is partially DIDS sensitive. Am. J. Physiol. Cell Physiol. 289, C1448-C1456. doi: 10.1152/ajpcell.00313.2005

Brookes, N. (1997). Intracellular $\mathrm{pH}$ as a regulatory signal in astrocyte metabolism. Glia 21, 64-73. doi: 10.1002/(SICI)1098-1136(199709)21:1 \%3C64::AID-GLIA7\%3E3.3.CO;2-Z

Burette, A. C., Weinberg, R. J., Sassani, P., Abuladze, N., Kao, L., and Kurtz, I. (2012). The sodium-driven chloride/bicarbonate exchanger in presynaptic terminals. J. Comp. Neurol. 520, 1481-1492. doi: 10.1002/cne.22806

Chen, L.-M., Kelly, M. L., Parker, M. D., Bouyer, P., Gill, H. S., Felie, J. M., et al. (2008a). Expression and localization of $\mathrm{Na}$-driven $\mathrm{Cl}-\mathrm{HCO}_{3}{ }^{-}$ exchanger (SLC4A8) in rodent CNS. Neuroscience 153, 162-174. doi: 10.1016/j. neuroscience.2008.02.018

Chen, L.-M., Kelly, M. L., Rojas, J. D., Parker, M. D., Gill, H. S., Davis, B. A., et al. (2008b). Use of a new polyclonal antibody to study the distribution and glycosylation of the sodium-coupled bicarbonate transporter NCBE in rodent brain. Neuroscience 151, 374-385. doi: 10.1016/j.neuroscience.2007.10.015

Cheng, Y. M., Kelly, T., and Church, J. (2008). Potential contribution of a voltageactivated proton conductance to acid extrusion from rat hippocampal neurons. Neuroscience 151, 1084-1098. doi: 10.1016/j.neuroscience.2007.12.007

Chesler, M. (2003). Regulation and modulation of $\mathrm{pH}$ in the brain. Physiol. Rev. 83, 1183-1221. doi: 10.1152/physrev.00010.2003

Chesler, M., and Kaila, K. (1992). Modulation of $\mathrm{pH}$ by neuronal activity. Trends Neurosci. 15, 396-402. doi: 10.1016/0166-2236(92)90191-A

Chesler, M., and Kraig, R. P. (1989). Intracellular $\mathrm{pH}$ transients of mammalian astrocytes. J. Neurosci. 9, 2011-2019.

Choi, H. B., Gordon, G. R. J., Zhou, N., Tai, C., Rungta, R. L., Martinez, J., et al. (2012). Metabolic communication between astrocytes and neurons via bicarbonate-responsive soluble adenylyl cyclase. Neuron 75, 1094-1104. doi: 10.1016/j.neuron.2012.08.032

Choi, I., Aalkjaer, C., Boulpaep, E. L., and Boron, W. F. (2000). An electroneutral sodium/bicarbonate cotransporter NBCn1 and associated sodium channel. Nature 405, 571-575. doi: 10.1038/35014615

Christensen, H. L., Nguyen, A. T., Pedersen, F. D., and Damkier, H. H. (2013). $\mathrm{Na}^{+}$ dependent acid-base transporters in the choroid plexus; insights from slc4 and slc9 gene deletion studies. Front. Physiol. 4:304. doi: 10.3389/fphys.2013.00304

Church, J. (1992). A change from $\mathrm{HCO}_{3}-\mathrm{CO}_{2}$ to hepes-buffered medium modifies membrane properties of rat CAl pyramidal neurones in vitro. J. Physiol. 455, 51-71.

Church, J., Baxter, K. A., and McLarnon, J. G. (1998). pH modulation of $\mathrm{Ca}^{2+}$ responses and a $\mathrm{Ca}^{2+}$-dependent $\mathrm{K}^{+}$channel in cultured rat hippocampal neurones. J. Physiol. 511(Pt 1), 119-132. doi: 10.1111/j.1469-7793.1998.119bi.x

Coley, A. A., Ruffin, V. A., Moss, F. J., Hopfer, U., and Boron, W. F. (2013). Immunocytochemical identification of electroneutral $\mathrm{Na}^{+}$-coupled transporters in freshly dissociated mouse medullary raphé neurons. Neuroscience 246, 451-467. doi: 10.1016/j.neuroscience.2013.02.064

Cooper, D. S., Saxena, N. C., Yang, H. S., Lee, H. J., Moring, A. G., Lee, A., et al. (2005). Molecular and functional characterization of the electroneutral $\mathrm{Na} / \mathrm{HCO}_{3}$ cotransporter $\mathrm{NBCn} 1$ in rat hippocampal neurons. J. Biol. Chem. 280, 17823-17830. doi: 10.1074/jbc.M408646200

Cooper, D. S., Yang, H. S., He, P., Kim, E., Rajbhandari, I., Yun, C. C., et al. (2009). Sodium/bicarbonate cotransporter NBCn1/slc4a7 increases cytotoxicity in magnesium depletion in primary cultures of hippocampal neurons. Eur. J. Neurosci. 29, 437-446. doi: 10.1111/j.1460-9568.2008.06611.x

Coulter, K. L., Périer, F., Redeke, C. M., and Vanderberg, C. A. (1995). Identification and molecular localization of a $\mathrm{pH}$-sensing domain for the inward rectifier potassium channel HIR. Neuron 15, 1157-1168. doi: 10.1016/08966273(95)90103-5

Counillon, L., Franchi, A., and Pouysségur, J. (1993). A point mutation of the $\mathrm{Na}^{+} / \mathrm{H}^{+}$exchanger gene (NHE1) and amplification of the mutated allele confer amiloride resistance upon chronic acidosis. PNAS 90, 4508-4512. doi: 10.1073/pnas.90.10.4508

Cox, G. A., Lutz, C. M., Yang, C. L., Biemesderfer, D., Bronson, R. T., Fu, A., et al. (1997). Sodium/hydrogen exchanger gene defect in slow-wave epilepsy mutant mice. Cell 91, 139-148. doi: 10.1016/S0092-8674(01)80016-7

Damkier, H. H., Brown, P. D., and Praetorius, J. (2010a). Epithelial pathways in choroid plexus electrolyte transport. Physiology (Bethesda) 25, 239-249. doi: 10.1152/physiol.00011.2010 
Damkier, H. H., Aalkjaer, C., and Praetorius, J. (2010b). Na ${ }^{+}$-dependent $\mathrm{HCO}_{3}{ }^{-}$ import by the slc4a10 gene product involves $\mathrm{Cl}^{-}$export. J. Biol. Chem. 285, 26998-27007. doi: 10.1074/jbc.M110.108712

Damkier, H. H., Brown, P. D., and Praetorius, J. (2013). Cerebrospinal fluid secretion by the choroid plexus. Physiol. Rev. 93, 1847-1892. doi: 10.1152/physrev.00004.2013

Damkier, H. H., Nielsen, S., and Praetorius, J. (2007). Molecular expression of SLC4-derived $\mathrm{Na}^{+}$-dependent anion transporters in selected human tissues. Am. J. Physiol. Regul. Integr. Comp. Physiol. 293, R2136-R2146. doi: 10.1152/ajpregu.00356.2007

Dean, J. B., Kinkade, E. A., and Putnam, R. W. (2001). Cell-cell coupling in $\mathrm{CO}_{2} / \mathrm{H}^{+}$-excited neurons in brainstem slices. Respir. Physiol. 129, 83-100. doi: 10.1016/S0034-5687(01)00284-5

Deitmer, J. W., and Rose, C. R. (1996). pH regulation and proton signalling by glial cells. Prog. Neurobiol. 48, 73-103. doi: 10.1016/0301-0082(95)00039-9

Demetrius, L. A., and Simon, D. K. (2012). An inverse-Warburg effect and the origin of Alzheimer's disease. Biogerontology 13, 583-594. doi: 10.1007/s10522012-9403-6

Demirci, F. Y. K., Chang, M.-H., Mah, T. S., Romero, M. F., and Gorin, M. B. (2006). Proximal renal tubular acidosis and ocular pathology: a novel missense mutation in the gene (SLC4A4) for sodium bicarbonate cotransporter protein (NBCe1). Mol. Vis. 12, 324-330.

Diering, G. H., Mills, F., Bamji, S. X., and Numata, M. (2011). Regulation of dendritic spine growth through activity-dependent recruitment of the brain-enriched $\mathrm{Na}^{+} / \mathrm{H}^{+}$exchanger NHE5. Mol. Biol. Cell 22, 2246-2257. doi: 10.1091/mbc.E11-01-0066

Donowitz, M., Ming Tse, C., and Fuster, D. (2013). SLC9/NHE gene family, a plasma membrane and organellar family of $\mathrm{Na}+/ \mathrm{H}+$ exchangers. Mol. Aspects Med. 34, 236-251. doi: 10.1016/j.mam.2012.05.001

Douglas, R. M., Trouth, C. O., James, S. D., Sexcius, L. M., Kc, P., Dehkordi, O., et al. (2001). Decreased CSF pH at ventral brain stem induces widespread c-Fos immunoreactivity in rat brain neurons. J. Appl. Physiol. 90, 475-485.

Duprat, F., Lesage, F., Fink, M., Reyes, R., Heurteaux, C., and Lazdunski, M. (1997). TASK, a human background $\mathrm{K}^{+}$channel to sense external $\mathrm{pH}$ variations near physiological pH. EMBO J. 16, 5464-5471. doi: 10.1093/emboj/16.17.5464

Ekdahl, C. T., Kokaia, Z., and Lindvall, O. (2009). Brain inflammation and adult neurogenesis: the dual role of microglia. Neuroscience 158, 1021-1029. doi: 10.1016/j.neuroscience.2008.06.052

Giebisch, G., and Windhager, E. E. (2009). "Transport of acids and bases," in Medical Physiology. A Cellular and Molecular Approach, eds W. F. Boron and E. L. Boulpaep (Philadelphia, PA: Elsevier Saunders), 851-865.

Giffard, R. G., Monyer, H., Christine, C. W., and Choi, D. W. (1990). Acidosis reduces NMDA receptor activation, glutamate neurotoxicity, and oxygenglucose deprivation neuronal injury in cortical cultures. Brain Res. 506, 339-342. doi: 10.1016/0006-8993(90)91276-M

Grichtchenko, I. I., Choi, I., Zhong, X., Bray-Ward, P., Russell, J. M., and Boron, W. F. (2001). Cloning, characterization, and chromosomal mapping of a human electroneutral $\mathrm{Na}^{+}$-driven $\mathrm{Cl}-\mathrm{HCO}_{3}$ exchanger. J. Biol. Chem. 276, 8358-8363. doi: 10.1074/jbc.C000716200

Gu, X. Q., Yao, H., and Haddad, G. G. (2001). Increased neuronal excitability and seizures in the $\mathrm{Na}^{+} / \mathrm{H}^{+}$exchanger null mutant mouse. Am. J. Physiol. Cell Physiol. 281, C496-503.

Gurnett, C. A., Veile, R., Zempel, J., Blackburn, L., Lovett, M., and Bowcock, A. (2008). Disruption of sodium bicarbonate transporter SLC4A10 in a patient with complex partial epilepsy and mental retardation. Arch. Neurol. 65, 550-553. doi: 10.1001/archneur.65.4.550

Halestrap, A. P. (2012). The monocarboxylate transporter family-structure and functional characterization. IUBMB Life 64, 1-9. doi: 10.1002/iub.573

Hentschke, M., Wiemann, M., Hentschke, S., Kurth, I., Hermans-Borgmeyer, I., Seidenbecher, T., et al. (2006). Mice with a targeted disruption of the $\mathrm{Cl}^{-} / \mathrm{HCO}_{3}{ }^{-}$exchanger AE3 display a reduced seizure threshold. Mol. Cell. Biol. 26, 182-191. doi: 10.1128/MCB.26.1.182-191.2006

Hills, A. G. (1973). pH and the Henderson-Hasselbalch equation. Am. J. Med. 55, 131-133. doi: 10.1016/0002-9343(73)90160-5

Hodges, M. R., and Richerson, G. B. (2010). Medullary serotonin neurons and their roles in central respiratory chemoreception. Respir. Physiol. Neurobiol. 173, 256-263. doi: 10.1016/j.resp.2010.03.006

Horita, S., Yamada, H., Inatomi, J., Moriyama, N., Sekine, T., Igarashi, T., et al. (2005). Functional analysis of NBC1 mutants associated with proximal renal tubular acidosis and ocular abnormalities. J. Am. Soc. Nephrol. 16, 2270-2278. doi: 10.1681/ASN.2004080667

Hormuzdi, S. G., Filippov, M. A., Mitropoulou, G., Monyer, H., and Bruzzone, R. (2004). Electrical synapses: a dynamic signaling system that shapes the activity of neuronal networks. Biochim. Biophys. Acta 1662, 113-137. doi: 10.1016/j.bbamem.2003.10.023

Hurn, P. D., Koehler, R. C., Norris, S. E., Schwentker, A. E., and Traystman, R. J. (1991). Bicarbonate conservation during incomplete cerebral ischemia with superimposed hypercapnia. Am. J. Physiol. 261, H853-859.

Igarashi, T., Inatomi, J., Sekine, T., Seki, G., Shimadzu, M., Tozawa, F., et al. (2001). Novel nonsense mutation in the $\mathrm{Na}^{+} / \mathrm{HCO}_{3}{ }^{-}$cotransporter gene (SLC4A4) in a patient with permanent isolated proximal renal tubular acidosis and bilateral glaucoma. J. Am. Soc. Nephrol. 12, 713-718.

Igarashi, T., Sekine, T., Inatomi, J., and Seki, G. (2002). Unraveling the molecular pathogenesis of isolated proximal renal tubular acidosis. JASN 13, 2171-2177. doi: 10.1097/01.ASN.0000025281.70901.30

Irie, T., Hara, M., Yasukura, T., Minamino, M., Omori, K., Matsuda, H., et al. (1998). Chloride concentration in cultured hippocampal neurons increases during long-term exposure to ammonia through enhanced expression of an anion exchanger. Brain Res. 806, 246-256. doi: 10.1016/S0006-8993(98)00700-8

Irwin, R. P., Lin, S. Z., Long, R. T., and Paul, S. M. (1994). N-methyl-D-aspartate induces a rapid, reversible, and calcium-dependent intracellular acidosis in cultured fetal rat hippocampal neurons. J. Neurosci. 14, 1352-1357.

Jacobs, S., Ruusuvuori, E., Sipilä, S. T., Haapanen, A., Damkier, H. H., Kurth, I., et al. (2008). Mice with targeted Slc4a10 gene disruption have small brain ventricles and show reduced neuronal excitability. Proc. Natl. Acad. Sci. U.S.A. 105, 311-316. doi: 10.1073/pnas.0705487105

Kahle, K. T., Rinehart, J., de los Heros, P., Louvi, A., Meade, P., Vazquez, N., et al. (2005). WNK3 modulates transport of $\mathrm{Cl}^{-}$in and out of cells: implications for control of cell volume and neuronal excitability. PNAS 102, 16783-16788. doi: 10.1073/pnas.0508307102

Kaila, K., Panula, P., Karhunen, T., and Heinonen, E. (1991). Fall in intracellular $\mathrm{pH}$ mediated by GABAA receptors in cultured rat astrocytes. Neurosci. Lett. 126, 9-12. doi: 10.1016/0304-3940(91)90358-Z

Kanaan, A., Douglas, R. M., Alper, S. L., Boron, W. F., and Haddad, G. G. (2007). Effect of chronic elevated carbon dioxide on the expression of acid-base transporters in the neonatal and adult mouse. Am. J. Physiol. Regul. Integr. Comp. Physiol. 293, R1294-R1302. doi: 10.1152/ajpregu.00261.2007

Kao, L., Kurtz, L. M., Shao, X., Papadopoulos, M. C., Liu, L., Bok, D., et al. (2011). Severe neurologic impairment in mice with targeted disruption of the electrogenic sodium bicarbonate cotransporter NBCe2 (Slc4a5 Gene). J. Biol. Chem. 286, 32563-32574. doi: 10.1074/jbc.M111.249961

Kersh, A. E., Hartzler, L. K., Havlin, K., Hubbell, B. B., Nanagas, V., Kalra, A., et al. (2009). pH regulating transporters in neurons from various chemosensitive brainstem regions in neonatal rats. Am. J. Physiol. Regul. Integr. Comp. Physiol. 297, R1409-R1420. doi: 10.1152/ajpregu.91038.2008

Kiwull-Schöne, H., Kiwull, P., Frede, S., and Wiemann, M. (2007). Role of brainstem sodium/proton exchanger 3 for breathing control during chronic acid base imbalance. Am. J. Respir. Crit. Care Med. 176, 513-519. doi: 10.1164/rccm.200703-347OC

Kiwull-Schöne, H., Wiemann, M., Frede, S., Bingmann, D., Wirth, K. J., Heinelt, U., et al. (2001). A novel inhibitor of the $\mathrm{Na}^{+} / \mathrm{H}^{+}$exchanger type 3 activates the central respiratory $\mathrm{CO}_{2}$ response and lowers the apneic threshold. Am. J. Respir. Crit. Care Med. 164, 1303-1311. doi: 10.1164/ajrccm.164.7.2010147

Klanke, C. A., Su, Y. R., Callen, D. F., Wang, Z., Meneton, P., Baird, N., et al. (1995). Molecular cloning and physical and genetic mapping of a novel human $\mathrm{Na}^{+} / \mathrm{H}^{+}$ exchanger (NHE5/SLC9A5) to chromosome 16q22.1. Genomics 25, 615-622. doi: 10.1016/0888-7543(95)80002-4

Kobayashi, S., Morgans, C. W., Casey, J. R., and Kopito, R. R. (1994). AE3 anion exchanger isoforms in the vertebrate retina: developmental regulation and differential expression in neurons and glia. J. Neurosci. 14, 6266-6279.

Kopito, R. R., Lee, B. S., Simmons, D. M., Lindsey, A. E., Morgans, C. W., and Schneider, K. (1989). Regulation of intracellular $\mathrm{pH}$ by a neuronal homolog of the erythrocyte anion exchanger. Cell 59, 927-937. doi: 10.1016/00928674(89)90615-6

Krepischi, A. C. V., Knijnenburg, J., Bertola, D. R., Kim, C. A., Pearson, P. L., Bijlsma, E., et al. (2010). Two distinct regions in 2q24.2-q24.3 associated with idiopathic epilepsy. Epilepsia 51, 2457-2460. doi: 10.1111/j.1528-1167.2010. 02742.x 
Loeschcke, H. H., De Lattre, J., Schläfke, M. E., and Trouth, C. O. (1970). Effects on respiration and circulation of electrically stimulating the ventral surface of the medulla oblongata. Respir. Physiol. 10, 184-197. doi: 10.1016/00345687(70)90082-4

Ma, E., and Haddad, G. G. (1997). Expression and localization of $\mathrm{Na}^{+} / \mathrm{H}^{+}$ exchangers in rat central nervous system. Neuroscience 79, 591-603. doi: 10.1016/S0306-4522(96)00674-4

Majumdar, D., Maunsbach, A. B., Shacka, J. J., Williams, J. B., Berger, U. V., Schultz, K. P., et al. (2008). Localization of electrogenic Na/bicarbonate cotransporter NBCe1 variants in rat brain. Neuroscience 155, 818-832. doi: 10.1016/j.neuroscience.2008.05.037

Makani, S., and Chesler, M. (2007). Endogenous alkaline transients boost postsynaptic NMDA receptor responses in hippocampal CA1 pyramidal neurons. J. Neurosci. 27, 7438-7446. doi: 10.1523/JNEUROSCI.2304-07.2007

Makani, S., and Chesler, M. (2010). Rapid rise of extracellular pH evoked by neural activity is generated by the plasma membrane calcium ATPase. J. Neurophysiol. 103, 667-676. doi: 10.1152/jn.00948.2009

Manning Fox, J. E., Meredith, D., and Halestrap, A. P. (2000). Characterisation of human monocarboxylate transporter 4 substantiates its role in lactic acid efflux from skeletal muscle. J. Physiol. 529, 285-293. doi: 10.1111/j.14697793.2000.00285.x

Mattson, M. P., Pedersen, W. A., Duan, W., Culmsee, C., and Camandola, S. (1999). Cellular and molecular mechanisms underlying perturbed energy metabolism and neuronal degeneration in Alzheimer's and Parkinson's diseases. Ann. N.Y. Acad. Sci. 893, 154-175. doi: 10.1111/j.1749-6632.1999. tb07824.x

McDonald, J. W., Bhattacharyya, T., Sensi, S. L., Lobner, D., Ying, H. S., Canzoniero, L. M. T., et al. (1998). Extracellular acidity potentiates AMPA receptor-mediated cortical neuronal death. J. Neurosci. 18, 6290-6299.

Meech, R. (2012). A contribution to the history of the proton channel. Wiley Interdiscip. Rev. Membr. Transp. Signal. 1, 533-557. doi: 10.1002/ wmts. 59

Meech, R. W., and Thomas, R. C. (1987). Voltage-dependent intracellular pH in Helix aspersa neurones. J. Physiol. 390, 433-452.

Meier, S., Hübner, C. A., Groeben, H., Peters, J., Bingmann, D., and Wiemann, M. (2007). Expression of anion exchanger 3 influences respiratory rate in awake and isoflurane anesthetized mice. J. Physiol. Pharmacol. 58(Suppl. 5), 371-378.

Millar, I. D., and Brown, P. D. (2008). NBCe2 exhibits a $3 \mathrm{HCO}_{3}{ }^{-}: 1 \mathrm{Na}^{+}$stoichiometry in mouse choroid plexus epithelial cells. Biochem. Biophys. Res. Commun. 373, 550-554. doi: 10.1016/j.bbrc.2008.06.053

Mitchell, R. A., Loeschcke, H. H., Severinghaus, J. W., Richardson, B. W., and Massion, W. H. (1963). Regions of respiratory chemosensitivity on the surface of the medulla. Ann. N.Y. Acad. Sci. 109, 661-681. doi: 10.1111/j.1749-6632. 1963.tb13496.x

Orlowski, J. (1993). Heterologous expression and functional properties of amiloride high affinity (NHE-1) and low affinity (NHE-3) isoforms of the rat Na/H exchanger. J. Biol. Chem. 268, 16369-16377.

Orlowski, J., and Grinstein, S. (2004). Diversity of the mammalian sodium/proton exchanger SLC9 gene family. Pflugers Arch. 447, 549-565. doi: 10.1007/s00424003-1110-3

OuYang, Y. B., Mellergård, P., Kristián, T., Kristiánova, V., and Siesjö, B. K. (1994). Influence of acid-base changes on the intracellular calcium concentration of neurons in primary culture. Exp. Brain Res. 101, 265-271. doi: 10.1007/BF00228746

Park, H. J., Rajbhandari, I., Yang, H. S., Lee, S., Cucoranu, D., Cooper, D. S., et al. (2010). Neuronal expression of sodium/bicarbonate cotransporter NBCn1 (SLC4A7) and its response to chronic metabolic acidosis. Am. J. Physiol. Cell Physiol. 298, C1018-C1028. doi: 10.1152/ajpcell.00492.2009

Parker, M. D., and Boron, W. F. (2013). The divergence, actions, roles, and relatives of sodium-coupled bicarbonate transporters. Physiol. Rev. 93, 803-959. doi: 10.1152/physrev.00023.2012

Parker, M. D., Musa-Aziz, R., Rojas, J. D., Choi, I., Daly, C. M., and Boron, W. F. (2008). Characterization of human SLC4A10 as an electroneutral $\mathrm{Na} / \mathrm{HCO} 3$ cotransporter $(\mathrm{NBCn} 2)$ with $\mathrm{Cl}^{-}$self-exchange activity. J. Biol. Chem. 283, 12777-12788. doi: 10.1074/jbc.M707829200

Pavlov, I., Kaila, K., Kullmann, D. M., and Miles, R. (2013). Cortical inhibition, $\mathrm{pH}$ and cell excitability in epilepsy: what are optimal targets for antiepileptic interventions? J. Physiol. 591, 765-774. doi: 10.1113/jphysiol.2012.237958
Pick, U., and Karlish, S. J. (1982). Regulation of the conformation transition in the Ca-ATPase from sarcoplasmic reticulum by $\mathrm{pH}$, temperature, and calcium ions. J. Biol. Chem. 257, 6120-6126.

Pizzonia, J. H., Ransom, B. R., and Pappas, C. A. (1996). Characterization of $\mathrm{Na}^{+} / \mathrm{H}^{+}$exchange activity in cultured rat hippocampal astrocytes. J. Neurosci. Res. 44, 191-198. doi: 10.1002/(SICI)1097-4547(19960415)44:2\%3C191::AIDJNR12\%3E3.3.CO;2-B

Poetsch, M., Nottebaum, B. J., Wingenfeld, L., Frede, S., Vennemann, M., and Bajanowski, T. (2010). Impact of sodium/proton exchanger 3 gene variants on sudden infant death syndrome. J. Pediatry 156, 44-48.e1. doi: 10.1016/j.jpeds.2009.07.018

Putnam, R. W. (2001). Intracellular pH regulation of neurons in chemosensitive and nonchemosensitive areas of brain slices. Respir. Physiol. 129, 37-56. doi: 10.1016/S0034-5687(01)00281-X

Raley-Susman, K. M., Cragoe, E. J. Jr., Sapolsky, R. M., and Kopito, R. R. (1991). Regulation of intracellular $\mathrm{pH}$ in cultured hippocampal neurons by an amiloride-insensitive Na+/H+ exchanger. J. Biol. Chem. 266, 2739-2745.

Raley-Susman, K. M., Sapolsky, R. M., and Kopito, R. R. (1993). $\mathrm{Cl}^{-} / \mathrm{HCO}_{3}{ }^{-}$ exchange function differs in adult and fetal rat hippocampal neurons. Brain Res. 614, 308-314. doi: 10.1016/0006-8993(93)91049-X

Ribas-Salgueiro, J. L., Matarredona, E. R., Sarmiento, M., Ribas, J., and Pásaro, R. (2009). Respiratory response to systemic inhibition of the $\mathrm{Na}^{+} / \mathrm{H}^{+}$ exchanger type 3 in intact rats. Respir. Physiol. Neurobiol. 165, 254-260. doi: 10.1016/j.resp.2008.12.011

Richerson, G. B. (2004). Serotonergic neurons as carbon dioxide sensors that maintain pH homeostasis. Nat. Rev. Neurosci. 5, 449-461. doi: 10.1038/nrn1409

Ritucci, N. A., Chambers-Kersh, L., Dean, J. B., and Putnam, R. W. (1998). Intracellular $\mathrm{pH}$ regulation in neurons from chemosensitive and nonchemosensitive areas of the medulla. Am. J. Physiol. 275, R1152-R1163.

Ro, H., and Carson, J. H. (2004). pH microdomains in oligodendrocytes. J. Biol. Chem. 279, 37115-37123. doi: 10.1074/jbc.M403099200

Romero, M. F., Hediger, M. A., Boulpaep, E. L., and Boron, W. F. (1997). Expression cloning and characterization of a renal electrogenic $\mathrm{Na}^{+} / \mathrm{HCO}_{3}{ }^{-}$cotransporter. Nature 387, 409-413. doi: 10.1038/387409a0

Roos, A., and Boron, W. F. (1981). Intracellular pH. Physiol. Rev. 61, 296-434.

Ruffin, V. A., Gu, X. Q., Zhou, D., Douglas, R. M., Sun, X., Trouth, C. O., et al. (2008). The sodium-activated potassium channel Slack is modulated by hypercapnia and acidosis. Neuroscience 151, 410-418. doi: 10.1016/j.neuroscience.2007.10.031

Sander, T., Toliat, M. R., Heils, A., Leschik, G., Becker, C., Rüschendorf, F., et al. (2002). Association of the 867Asp variant of the human anion exchanger 3 gene with common subtypes of idiopathic generalized epilepsy. Epilepsy Res. 51, 249-255. doi: 10.1016/S0920-1211(02)00152-3

Sassani, P., Pushkin, A., Gross, E., Gomer, A., Abuladze, N., Dukkipati, R., et al. (2002). Functional characterization of NBC4: a new electrogenic sodiumbicarbonate cotransporter. Am. J. Physiol. Cell Physiol. 282, C408-C416. doi: 10.1152/ajpcell.00409.2001

Schlaefke, M. E., See, W. R., and Loeschcke, H. H. (1970). Ventilatory response to alterations of $\mathrm{H}+$ ion concentration in small areas of the ventral medullary surface. Respir. Physiol. 10, 198-212. doi: 10.1016/0034-5687(70)90083-6

Schmitt, B. M., Berger, U. V., Douglas, R. M., Bevensee, M. O., Hediger, M. A., Haddad, G. G., et al. (2000). $\mathrm{Na}^{+} \mathrm{CO}_{3}-$ cotransporters in rat brain: expression in glia, neurons, and choroid plexus. J. Neurosci. 20, 6839-6848.

Schwiening, C. J., and Boron, W. F. (1994). Regulation of intracellular pH in pyramidal neurones from the rat hippocampus by $\mathrm{Na}^{+}$-dependent $\mathrm{Cl}^{-}-\mathrm{HCO}_{3}{ }^{-}$ exchange. J. Physiol. 475, 59-67.

Sebat, J., Lakshmi, B., Malhotra, D., Troge, J., Lese-Martin, C., Walsh, T., et al. (2007). Strong association of de novo copy number mutations with autism. Science 316, 445-449. doi: 10.1126/science.1138659

Sin, W.-C., Moniz, D. M., Ozog, M. A., Tyler, J. E., Numata, M., and Church, J. (2009). Regulation of early neurite morphogenesis by the $\mathrm{Na}+\mathrm{H}+$ exchanger NHE1. J. Neurosci. 29, 8946-8959. doi: 10.1523/JNEUROSCI.203009.2009

Sinning, A., and Hübner, C. A. (2013). Minireview: pH and synaptic transmission. FEBS Lett. 587, 1923-1928. doi: 10.1016/j.febslet.2013.04.045

Sinning, A., Liebmann, L., Kougioumtzes, A., Westermann, M., Bruehl, C., and Hübner, C. A. (2011). Synaptic glutamate release is modulated by the $\mathrm{Na}^{+}$-driven $\mathrm{Cl}^{-} / \mathrm{HCO}_{3}{ }^{-}$exchanger Slc4a8. J. Neurosci. 31, 7300-7311. doi: 10.1523/JNEUROSCI.0269-11.2011 
Smith, G. A., Brett, C. L., and Church, J. (1998). Effects of noradrenaline on intracellular $\mathrm{pH}$ in acutely dissociated adult rat hippocampal CA1 neurones. J. Physiol. 512(Pt 2), 487-505. doi: 10.1111/j.1469-7793.1998.487be.x

Sterling, D., and Casey, J. R. (1999). Transport activity of AE3 chloride/bicarbonate anion-exchange proteins and their regulation by intracellular $\mathrm{pH}$. Biochem. J. 344(Pt 1), 221-229. doi: 10.1042/0264-6021:3440221

Svichar, N., Esquenazi, S., Chen, H.-Y., and Chesler, M. (2011). Preemptive regulation of intracellular $\mathrm{pH}$ in hippocampal neurons by a dual mechanism of depolarization-induced alkalinization. J. Neurosci. 31, 6997-7004. doi: 10.1523/JNEUROSCI.6088-10.2011

Svichar, N., Waheed, A., Sly, W. S., Hennings, J. C., Hübner, C. A., and Chesler, M. (2009). Carbonic anhydrases CA4 and CA14 both enhance AE3-mediated $\mathrm{Cl}^{-}-\mathrm{HCO}_{3}{ }^{-}$exchange in hippocampal neurons. J. Neurosci. 29, 3252-3258. doi: 10.1523/JNEUROSCI.0036-09.2009

Tang, C. M., Dichter, M., and Morad, M. (1990). Modulation of the N-methylD-aspartate channel by extracellular $\mathrm{H}^{+}$. Proc. Natl. Acad. Sci. U.S.A. 87, 6445-6449. doi: 10.1073/pnas.87.16.6445

Thomas, R. C. (1976). The effect of carbon dioxide on the intracellular $\mathrm{pH}$ and buffering power of snail neurones. J. Physiol. 255, 715-735.

Tombaugh, G. C., and Somjen, G. G. (1996). Effects of extracellular pH on voltagegated $\mathrm{Na}^{+}, \mathrm{K}^{+}$and $\mathrm{Ca}^{2+}$ currents in isolated rat CAl neurons. J. Physiol. 493, 719-732.

Tombaugh, G. C., and Somjen, G. G. (1997). Differential Sensitivity to intracellular $\mathrm{pH}$ among high- and low-threshold $\mathrm{Ca}^{2+}$ currents in isolated rat CA1 neurons. J. Neurophysiol. 77, 639-653.

Traynelis, S. F., and Cull-Candy, S. G. (1990). Proton inhibition of N-methylD-aspartate receptors in cerebellar neurons. Nature 345, 347-350. doi: $10.1038 / 345347 \mathrm{a} 0$

Vergo, S., Craner, M. J., Etzensperger, R., Attfield, K., Friese, M. A., Newcombe, J., et al. (2011). Acid-sensing ion channel 1 is involved in both axonal injury and demyelination in multiple sclerosis and its animal model. Brain 134, 571-584. doi: 10.1093/brain/awq337

Vilas, G. L., Johnson, D. E., Freund, P., and Casey, J. R. (2009). Characterization of an epilepsy-associated variant of the human $\mathrm{Cl}^{-} / \mathrm{HCO}_{3}{ }^{-}$exchanger AE3. Am. J. Physiol. Cell Physiol. 297, C526-C536. doi: 10.1152/ajpcell.00572.2008

Vincent, A. M., TenBroeke, M., and Maiese, K. (1999). Neuronal intracellular pH directly mediates nitric oxide-induced programmed cell death. J. Neurobiol. 40, 171-184. doi: 10.1002/(SICI) 1097-4695(199908)40:2\%3C171::AIDNEU4\%3E3.0.CO;2-F

Virkki, L. V., Wilson, D. A., Vaughan-Jones, R. D., and Boron, W. F. (2002). Functional characterization of human NBC4 as an electrogenic $\mathrm{Na}^{+}-\mathrm{HCO}_{3}{ }^{-}$ cotransporter (NBCe2). Am. J. Physiol. Cell Physiol. 282, C1278-C1289. doi: 10.1152/ajpcell.00589.2001

Waldmann, R., Champigny, G., Bassilana, F., Heurteaux, C., and Lazdunski, M. (1997). A proton-gated cation channel involved in acid-sensing. Nature 386, 173-177. doi: 10.1038/386173a0

Wang, C. Z., Yano, H., Nagashima, K., and Seino, S. (2000). The $\mathrm{Na}^{+}$driven $\mathrm{Cl}^{-} / \mathrm{HCO}_{3}{ }^{-}$exchanger. Cloning, tissue distribution, and functional characterization. J. Biol. Chem. 275, 35486-35490. doi: 10.1074/jbc.C000 456200

Wiemann, M., Frede, S., Bingmann, D., Kiwull, P., and Kiwull-Schöne, H. (2005). Sodium/Proton exchanger 3 in the medulla oblongata and set point of breathing control. Am. J. Respir. Crit. Care Med. 172, 244-249. doi: 10.1164/rccm.2004111567OC

Wiemann, M., Frede, S., Tschentscher, F., Kiwull-Schöne, H., Kiwull, P., Bingmann, D., et al. (2008). NHE3 in the human brainstem: implication for the pathogenesis of the sudden infant death syndrome (SIDS)? Adv. Exp. Med. Biol. 605, 508-513. doi: 10.1007/978-0-387-73693-8_89

Wiemann, M., Schwark, J. R., Bonnet, U., Jansen, H. W., Grinstein, S., Baker, R. E., et al. (1999). Selective inhibition of the $\mathrm{Na}^{+} / \mathrm{H}^{+}$exchanger type 3 activates $\mathrm{CO}_{2} / \mathrm{H}^{+}$-sensitive medullary neurones. Pflugers Arch. 438, 255-262. doi: $10.1007 / \mathrm{s} 004240050907$

Wolosker, H., Rocha, J. B., Engelender, S., Panizzutti, R., Miranda, J., and de Meis, L. (1997). Sarco/endoplasmic reticulum Ca2+-ATPase isoforms: diverse responses to acidosis. Biochem. J. 321, 545-550.

Xia, Y., Zhao, P., Xue, J., Gu, X. Q., Sun, X., Yao, H., et al. (2003). Na ${ }^{+}$channel expression and neuronal function in the $\mathrm{Na}^{+} / \mathrm{H}^{+}$exchanger 1 null mutant mouse. J. Neurophysiol. 89, 229-236. doi: 10.1152/jn.00488.2002

Xue, J., Douglas, R. M., Zhou, D., Lim, J. Y., Boron, W. F., and Haddad, G. G. (2003). Expression of $\mathrm{Na}^{+} / \mathrm{H}^{+}$and $\mathrm{HCO}_{3}{ }^{-}$-dependent transporters in $\mathrm{Na}^{+} / \mathrm{H}^{+}$exchanger isoform 1 null mutant mouse brain. Neuroscience 122 , 37-46. doi: 10.1016/S0306-4522(03)00598-0

Yao, H., Ma, E., Gu, X. Q., and Haddad, G. G. (1999). Intracellular pH regulation of CA1 neurons in $\mathrm{Na}(+) / \mathrm{H}(+)$ isoform 1 mutant mice. J. Clin. Invest. 104, 637-645. doi: 10.1172/JCI6785

Zhao, P., Ma, M.-C., Qian, H., and Xia, Y. (2005). Down-regulation of delta-opioid receptors in $\mathrm{Na}^{+} / \mathrm{H}^{+}$exchanger 1 null mutant mouse brain with epilepsy. Neurosci. Res. 53, 442-446. doi: 10.1016/j.neures.2005.09.003

Conflict of Interest Statement: The authors declare that the research was conducted in the absence of any commercial or financial relationships that could be construed as a potential conflict of interest.

Received: 01 November 2013; accepted: 23 January 2014; published online: 13 February 2014.

Citation: Ruffin VA, Salameh AI, Boron WF and Parker MD (2014) Intracellular pH regulation by acid-base transporters in mammalian neurons. Front. Physiol. 5:43. doi: $10.3389 /$ fphys.2014.00043

This article was submitted to Membrane Physiology and Membrane Biophysics, a section of the journal Frontiers in Physiology.

Copyright (c) 2014 Ruffin, Salameh, Boron and Parker. This is an open-access article distributed under the terms of the Creative Commons Attribution License (CC BY). The use, distribution or reproduction in other forums is permitted, provided the original author(s) or licensor are credited and that the original publication in this journal is cited, in accordance with accepted academic practice. No use, distribution or reproduction is permitted which does not comply with these terms. 